\title{
IMPLEMENTASI WEB CAMERA SEBAGAI VISUAL INSPECTION OTOMATIS UNTUK PROSES PEMUTUAN UKURAN DAN TINGKAT KEMATANGAN BUAH TOMAT
}

\author{
Oleh : \\ Andrizal. ${ }^{1)}$, Dodon Yendri ${ }^{2)}$.Aulia Rossalina ${ }^{3)}$, \\ 1) Jurusan Teknik Elektro Politeknik Negeri Padang \\ ${ }^{2,3)}$ Jurusan Sistem Komputer, Fakultas Teknologi Informasi, Universitas Andalas \\ andrizalpoli@gmail.com
}

\begin{abstract}
Quality and sorting is one method to classify an observed object and the end result of the inspection process. Quality and sorting can be done manually or automatically where quality and one manually sorting can be done by utilizing the human senses. Quality automatically requires certain tools such as the use of digital cameras to replace the sensory function of the human eye as a visual inspection. By using a digital camera, the camera capture object images obtained is processed via image processing, the processing system can be used as an automated visual inspection for the decision making process quality and sorting. The ability to recognize objects in the form of camera pixel component, can be used to determine the size and color, while the components can be used to determine the level of maturity. This system implemented as automatic visual inspection to determine quality tomato fruit size and maturity level. Results of testing this system is able to recognize $100 \%$ ripe tomatoes and $73 \%$ were able to recognize the young tomato fruit, the overall ability of the system to recognize the maturity level of the tomato fruit was $86.15 \%$. While the tomatoes quality test based on class size with large, medium and small work 100\%. Recognize the success rate of fruit maturity is greatly influenced by the current lighting objects tomatoes in camera capture. We hope this research can be used as input data for the next stage as the data input to the system pemutuan and automatically sorting tomatoes.
\end{abstract}

Keywords : Visual Inspection, pixel, color, classification.

\section{PENDAHULUAN}

Penanganan pasca produksi memegang peranan penting dalam penentuan mutu hasil produk, terutama kegiatan sortasi dan pemutuan. Kegiatan sortasi dan pemutuan dapat dilakukan secara manual seperti dengan memanfaatkan panca indra manusia, sedangkan sortasi dan pemutuan otomatis menggunakan alat bantu berupa suatu sistem. Penggunaan panca indra vision manusia pada sistem pemutuan manual dapat digantikan dengan menggunakan kamera digital. Hal ini dilakukan dengan mengolah hasil capture gambar yang didapat melalui kamera digital.

Image hasil capture kamera digital mengandung komponen pixel dan komponen warna. Kedua komponen ini dapat digunakan untuk menentukan ukuran dan tingkat kematangan buah berdasarkan warna, seperti untuk klasifikasi ukuran dan tingkat 
kematangan buah tomat. Jadi dengan perkembangan metode pengolahan citra dapat dilakukan penentuan tingkat kematangan dan ukuran buah tomat tanpa merusaknya. ${ }^{[20]}$

Dengan memanfaatkan kemampuan webcam dan pengolahan citra sebagai visual inspection ini, diharapkan dapat digunakan untuk pengklasifikasian tingkat kematangan buah tomat muda dan buah tomat matang, dan ukuran tomat kecil, sedang dan besar.

Tanaman tomat (Lycopersicum esculentum Mill.) termasuk famili Solanaceae merupakan tanaman setahun yang berbentuk herbaceus (perdu) dan umumnya tumbuh baik pada ketinggian 600-900 m di atas permukaan laut. Pada dataran rendah tomat dapat tumbuh tetapi umurnya lebih singkat dan produksinya lebih rendah dibanding di dataran tinggi. ${ }^{[11]}$

\section{Pengolahan Citra}

Pengolahan citra pada dasarnya dilakukan dengan cara memodifikasi setiap titik dalam citra yang bertujuan untuk memperbaiki kualitas citra sehingga lebih mudah diinterpretasikan oleh manusia dan mesin (komputer). Teknik-teknik pengolahan citra biasanya mentransformasikan citra menjadi citra lain. Jadi input dan outputnya adalah sama-sama berupa citra ${ }^{[20]}$.

\section{Pixel}

Pixel adalah sebuah titik single didalam citra digital yang merupakan elemen individual terkecil yang mempunyai nilai-nilai terkuantisasai yang merepresentasikan brightness dari sebuah warna pada sebuah titik yang spesifik $^{[7]}$.

Nilai suatu pixel memiliki nilai dalam rentang tertentu, dari nilai minimum sampai nilai maksimum. Jangkauan yang digunakan berbeda-beda tergantung dari jenis warnanya. Namun secara umum jangkauannya adalah $0-255$. Citra dengan penggambaran seperti ini digolongkan kedalam citra integer. Berikut adalah jenis-jenis citra berdasarkan nilai pixelnya, sebagai berikut ${ }^{[21]}$ :

\section{a. Citra grayscale}

Citra grayscale disebut juga citra keabuan karena pada umumnya warna yang dipakai adalah antara hitam sebagai warna minimal dan warna putih sebagai warna maksimal, sehingga warna antaranya adalah abu-abu. Grayscale adalah warna-warna pixel dalam sebuah gambar yang dikonversi menjadi gambar abu-abu. Sistem grayscale hanya memerlukan 1 byte untuk menyimpan data, sehingga hanya mempunyai variasi dari 0(hitam) sampai 255(putih).

Ada beberapa macam untuk mengkonversi system warna RGB menjadi grayscale yaitu:

1. Dengan merata-rata setiap komponen warna $\mathrm{R} \mathcal{F}^{-}, \mathcal{\gamma}, \boldsymbol{s}^{\circ}:=$

2. Dengan nilai ma 3 tilai RGB

Grayscale $=\operatorname{Max}[\mathrm{R}, \mathrm{B}, \mathrm{G}]$

3. Dengan menggunakan YUV (system pada NTSC) yaitu dengan cara mengambil komponen Y(iluminasi). Komponen $\mathrm{Y}$ dapat diperoleh dari system warna RGB dengan konversi: Grayscale $=0.299 \mathrm{R}+$ $0.587 \mathrm{G}+0.114 \mathrm{~B}$

b. Citra warna (24bit)

Setiap pixel dari citra warna 24bit diwakili dengan 24 bit sehingga total 16777216 variasi warna. Setiap poin informasi pixel (RGB) disimpan kedalm 1 byte data. 8 bit pertama menyimpan nilai biru kemudian di ikuti dengan nilai hijau pada 8 bit kedua dan pada 8 bit terakhir merupakan warna merah. Setiap titik (pixel) pada citra warna mewakili warna yang merupakan kombinasi dari tiga warna dasar yaitu merah hijau biru citra RGB (Red Green Blue). Setiap warna dasar mempunyai intensitas 
sendiri dengan nilai maksimum 255 (8 bit).

Red = warna minimal putih, warna maksimal merah

Green=warna minimal putih, warna maksimal hijau

Blue = warna minimal putih, warna maksimal biru

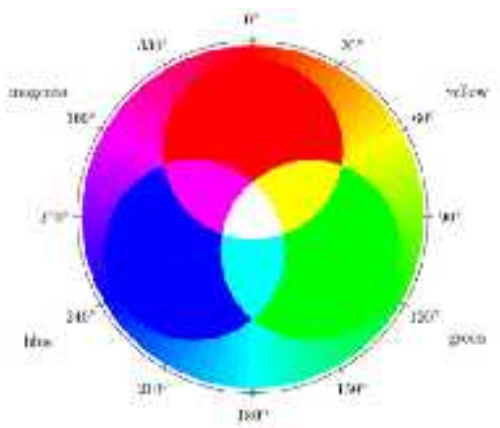

11느

Gambar 1. Pemetaan RGB yang dicampurkan

\section{Histogram Citra}

Histogram citra adalah grafik yang menggambarkan penyebaran nilai-nilai intensitas pixel dari suatu citra atau bagian tertentu di dalam citra. Dari sebuah histogram dapat diketahui frekuensi kemunculan nisbi (relative) dari intensitas pada citra tersebut. Histogram juga dapat menunjukan banyak hal tentang kecerahan (brightness) dan kontras (contrast) dari sebuah gambar. Karena itu, histogram adalah alat bantu yang berharga dalam pekerjaan pebgolahan citra baik secara kualitatif maupun kuantitatif.

Histogram citra banyak memberikan informasi penting sebagai berikut $:^{[21]}$

a. Nilai $h i$ menyatakan pluang (probability) pixel, $\mathrm{P}(i)$, dengan derajat keabuaan $i$. Jumlah seluruh nilai hi sama dengan dengan 1 ,atau

$$
\sum_{i=0}^{L-1} h i
$$

Peluang suatu pixel memiliki derajat keabuan lebih kecil atau sama dengan derajat keabuan tertentu adalah jumlah hi, untuk $0 \leq \mathrm{i} \leq \mathrm{j}$, atau

$$
\sum_{i=0}^{j} \quad h i=P(i \leq j) \quad 0 \leq
$$

b. Puncak histogram menunjukan intensitas pixel yang menonjol. Lebar dari puncak menunjukan rentang kontras dari suatu gambar. Citra yamg mempunyai kontras yang terlalu terang (overexposed) atau terlalu gelap (underexposed) memiliki histogram yang sempit. Histogramnya terlihat hanya menggunakan setengah dari daerah derajat keabuaan. Citra yang baik memiliki histogram yang mengisi daerah derajat keabuaan secara penuh.
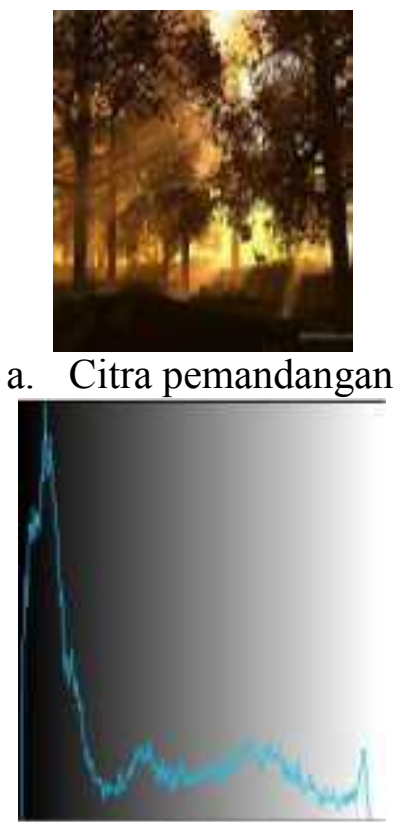

b. Histogram

Gambar 2. Citra Dengan Hitogramnya

\section{METODOLOGI PENELITIAN}

Visual inspection terhadap suatu objek dapat dilakukan dengan mengenali ciriciri dari objek yang diamati tersebut melalui panca indra misalnya melalui mata. Penggunaan web camera dapat digunakan sebagai pengganti fungsi 
mata untuk mengamati buah tomat. Hasil citra capture dari kamera diolah menggunakan pengolahan citra untuk mendapatkan ciri-ciri dari objek buah tomat. Adapun komponen citra yang dapat digunakan adalah :

a. Pixel digunakan untuk menentukan ukuran. Jumlah pixel dari suatu objek buah tomat yang diamati jika jarak kamera dengan objek tetap akan berbanding lurus dengan ukuran dari objek yang diamati.

b. Komponen warna Red, Green dan Blue (RGB) digunakan untuk menentukan tingkat kematangan. Unsur-unsur RGB yang terbentuk dari buah tomat muda (belum masak) dan buah matang (masak) dapat digunakan sebagai penentu tingkat kematangan.

\section{HASIL PENELITIAN}

Pengambilan keputusan pada perancangan software ini yaitu mencari selisih pixel pada data sampel untuk menentukan ukuran tomat kecil, sedang dan besar. Untuk menentukan tomat masak dan tomat muda ditentukan oleh nilai Red (R) atau Green (G) yang dominan.

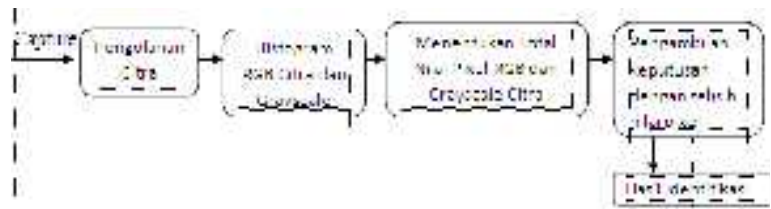

Gambar 3. Blok diagram sistem

Pengujian dilakukan untuk mengetahui apakah program dapat berjalan sebagai mana mestinya. Selain itu menganalisa terhadap data-data yang diperoleh dari sistem saat dijalankan. Sehingga didapatkan kesimpulan bagaimana hasil pendeteksian kematangan dan ukuran buah tomat tersebut.

Pada pengujian sistem yang dilakukan, menggunakan data yang berasal dari webcame external dengan format gambar yang dihasilkan adalah bitmap ukuran gambar yang ditangkap 640x480 pixel. Gambar yang diambil adalah gambar tomat matang dan gambar tomat muda dengan ukuran yang berbeda-beda untuk setiap tingkat kematangan (kecil, sedang, besar). Peng-capture-an gambar diambil satu sisi, sisi depan saja. Dan Jarak antara tomat dengan webcame dibuat konstan, yaitu $22 \mathrm{~cm}$.

Sistem yang dibuat menggunakan bahasa pemrograman Delphi. Sistem ini terdiri dari 5 form menu, setelah sistem dijalankan yang akan muncul pertama sekali yaitu form menu utama yaitu berisi menu program dan judul dari sistem yang dibuat.

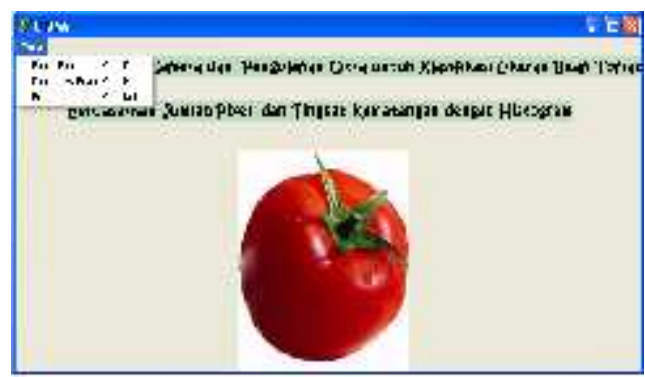

Gambar 4. Form Menu Utama

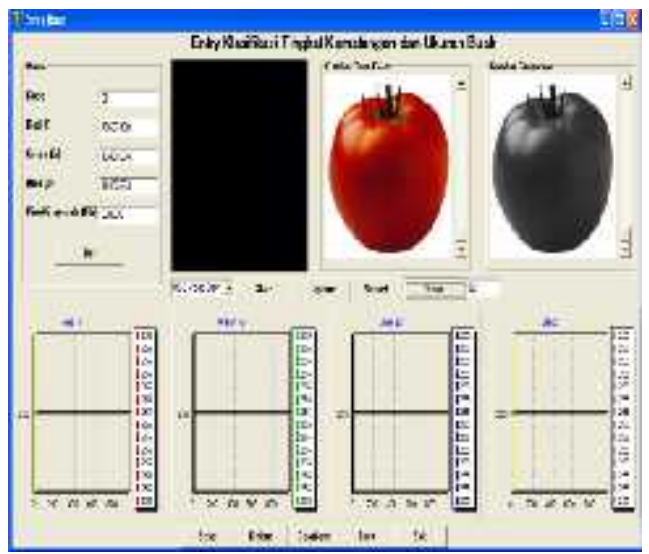

Gambar 5. Form Entry data base 


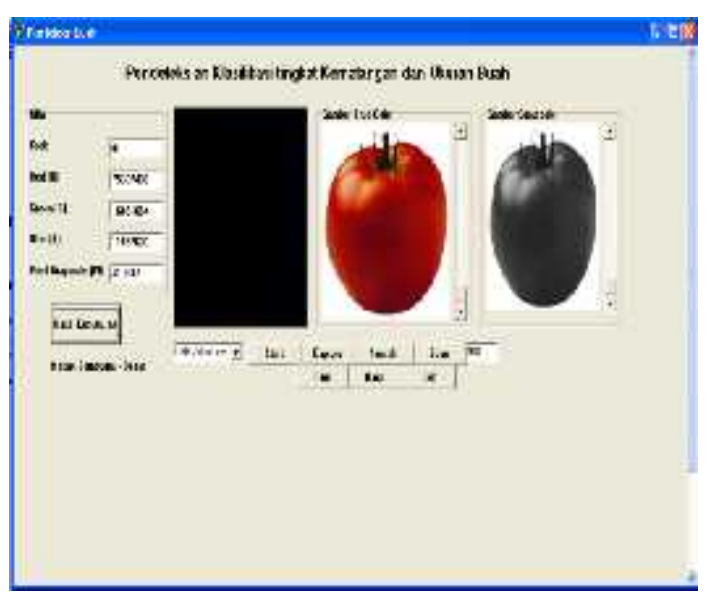

Gambar 6. Form uji sistem

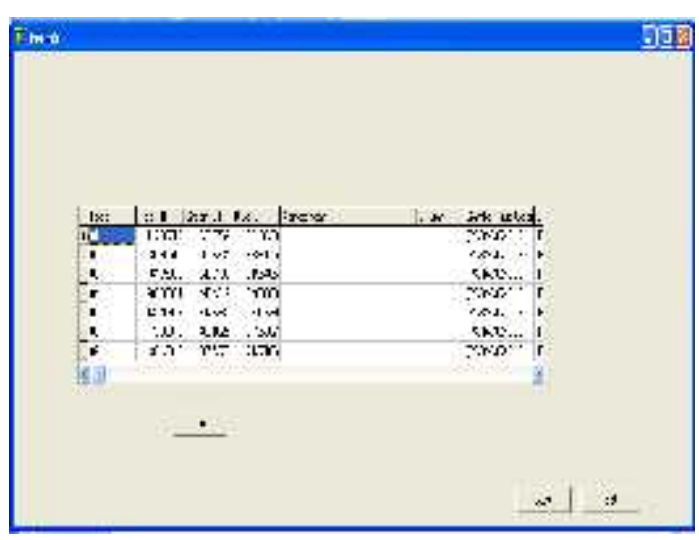

Gambar 7. Form Database

\section{Pengambilan Data Sampel}

Proses pengambilan data sampel tomat merah dan tomat hijau dengan berbagai ukuran kecil, sedang dan besar adalah untuk menjadikan data sampel tomat tersebut sebagai referensi untuk melakukan pengujian. Sampel tomat yang dijadikan sebagai referensi didapatkan dengan 6 kali capture untuk setiap dengan tingkat kematangan berbeda.

Table 1. Nilai dari Data Sampel Tomat Masak - Besar

\begin{tabular}{|c|r|c|r|r|}
\hline Kode & \multicolumn{1}{|c|}{$\begin{array}{c}\text { Red } \\
\text { (R) }\end{array}$} & $\begin{array}{c}\text { Green } \\
(\mathbf{G})\end{array}$ & $\begin{array}{c}\text { Blue } \\
\text { (B) }\end{array}$ & $\begin{array}{c}\text { Pixel } \\
\text { Grayscale } \\
\text { (PG) }\end{array}$ \\
\hline 0001 & 1661634 & 9321351 & 764166 & 113616 \\
& 3 & & 4 & \\
\hline 0002 & 1597489 & 9600364 & 778354 & 2 \\
& 2 & & 2 & \\
\hline
\end{tabular}

\begin{tabular}{|l|r|r|r|r|}
\hline & & & & \\
\hline 0003 & 1435307 & 7695246 & 659966 & 101244 \\
& 5 & & 1 & \\
\hline 0004 & 1330607 & 8545283 & 685276 & 95645 \\
& 4 & & 6 & \\
\hline 0005 & 1634557 & 9551890 & 788977 & 112392 \\
& 1 & & 7 & 95320 \\
\hline 0006 & 1351958 & 7860275 & 646542 & \\
& 8 & & 7 & 104900.2 \\
\hline $\begin{array}{l}\text { Rata- } \\
\text { Rata }\end{array}$ & 1501925 & 8762402 & 720547 & \\
\hline
\end{tabular}

Table 2. Nilai dari Data Sampel Tomat

\begin{tabular}{|c|c|c|c|c|}
\hline Kode & $\begin{array}{c}\text { Red } \\
\text { (R) }\end{array}$ & $\begin{array}{c}\text { Green } \\
\text { (G) }\end{array}$ & $\begin{array}{c}\text { Blue } \\
\text { (B) }\end{array}$ & $\begin{array}{c}\text { Pixel } \\
\text { Grayscale } \\
\text { (PG) }\end{array}$ \\
\hline 0007 & $\begin{array}{r}1106064 \\
7\end{array}$ & 5031398 & $\begin{array}{r}448553 \\
1\end{array}$ & 70719 \\
\hline 0008 & $\begin{array}{r}1137083 \\
7\end{array}$ & 5968609 & $\begin{array}{r}513963 \\
5\end{array}$ & 80828 \\
\hline 0009 & $\begin{array}{r}1101081 \\
0\end{array}$ & 5512024 & $\begin{array}{r}478402 \\
6\end{array}$ & 73685 \\
\hline 0010 & 9641056 & 4820437 & $\begin{array}{r}426180 \\
6\end{array}$ & 67809 \\
\hline 0011 & $\begin{array}{r}1174746 \\
7\end{array}$ & 5170666 & $\begin{array}{r}458113 \\
8\end{array}$ & 65950 \\
\hline 0012 & $\begin{array}{r}1172349 \\
1\end{array}$ & 6115312 & $\begin{array}{r}496111 \\
5\end{array}$ & 72693 \\
\hline $\begin{array}{l}\text { Rata- } \\
\text { Rata }\end{array}$ & $\begin{array}{r}1109238 \\
5\end{array}$ & 5436408 & $\begin{array}{r}470220 \\
9\end{array}$ & 71947.33 \\
\hline
\end{tabular}

Table 3. Nilai dari Data Sampel Tomat

\begin{tabular}{|c|c|c|c|c|}
\hline \multicolumn{5}{|c|}{ Masak - Kecil } \\
\hline Kode & $\begin{array}{c}\text { Red } \\
\text { (R) }\end{array}$ & $\begin{array}{c}\text { Green } \\
\text { (G) }\end{array}$ & $\begin{array}{c}\text { Blue } \\
\text { (B) }\end{array}$ & $\begin{array}{c}\text { Pixel } \\
\text { Grayscale } \\
\text { (PG) }\end{array}$ \\
\hline 0013 & 5514024 & 2684768 & $\begin{array}{r}240759 \\
8\end{array}$ & 37852 \\
\hline 0014 & 7493875 & 2991190 & $\begin{array}{r}276826 \\
2\end{array}$ & 42284 \\
\hline 0015 & 5832510 & 2919823 & $\begin{array}{r}265067 \\
1\end{array}$ & 41432 \\
\hline 0016 & 5280298 & 2568578 & $\begin{array}{r}233840 \\
9\end{array}$ & 35284 \\
\hline 0017 & 6721015 & 3248378 & $\begin{array}{r}289779 \\
2\end{array}$ & 46502 \\
\hline 0018 & 5389086 & 2557726 & $\begin{array}{r}222679 \\
3 \\
\end{array}$ & 34627 \\
\hline $\begin{array}{l}\text { Rata- } \\
\text { Rata }\end{array}$ & 6038468 & 2828411 & $\begin{array}{r}254825 \\
4 \\
\end{array}$ & 39663.5 \\
\hline
\end{tabular}




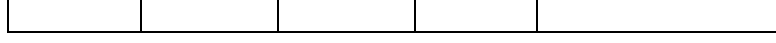

Table 4. Nilai dari Data Sampel Tomat Muda - Besar

\begin{tabular}{|l|c|c|c|r|}
\hline Kode & $\begin{array}{c}\text { Red } \\
(\mathbf{R})\end{array}$ & $\begin{array}{c}\text { Green } \\
(\mathbf{G})\end{array}$ & $\begin{array}{c}\text { Blue } \\
(\mathbf{B})\end{array}$ & $\begin{array}{c}\text { Pixel } \\
\text { Grayscale } \\
\text { (PG) }\end{array}$ \\
\hline 0019 & 12575866 & 12786224 & 8427103 & 73261 \\
\hline 0020 & 12689935 & 13201649 & 8400034 & 80312 \\
\hline 0021 & 10732732 & 11122479 & 6772508 & 68840 \\
\hline 0022 & 9717112 & 10210426 & 6802404 & 73536 \\
\hline 0023 & 13731497 & 13952464 & 9004252 & 90711 \\
\hline 0024 & 12509729 & 12978118 & 8486793 & 89363 \\
\hline $\begin{array}{l}\text { Rata- } \\
\text { Rata }\end{array}$ & 11992812 & 12375227 & 7982182 & 79337.17 \\
\hline
\end{tabular}

Table 5. Nilai dari Data Sampel Tomat Muda - Sedang

\begin{tabular}{|l|c|c|c|r|}
\hline Kode & $\begin{array}{c}\text { Red } \\
(\mathbf{R})\end{array}$ & $\begin{array}{c}\text { Green } \\
(\mathbf{G})\end{array}$ & $\begin{array}{c}\text { Blue } \\
(\mathbf{B})\end{array}$ & $\begin{array}{c}\text { Pixel } \\
\text { Grayscale } \\
\text { (PG) }\end{array}$ \\
\hline 0025 & 8576866 & 9128259 & 6016689 & 66749 \\
\hline 0026 & 7980200 & 8376530 & 5536855 & 63103 \\
\hline 0027 & 8739654 & 9171190 & 5971006 & 64344 \\
\hline 0028 & 7996475 & 8283194 & 5526513 & 57139 \\
\hline 0029 & 7924286 & 8220717 & 5458967 & 53153 \\
\hline 0030 & 8869350 & 9175307 & 5756960 & 62215 \\
\hline $\begin{array}{l}\text { Rata }- \\
\text { Rata }\end{array}$ & 8347805 & 8725866 & 5711165 & 61117.15 \\
\hline
\end{tabular}

Table 6. Nilai dari Data Sampel Tomat Muda - Kecil

\begin{tabular}{|c|r|c|r|r|}
\hline $\begin{array}{c}\text { Kod } \\
\mathbf{e}\end{array}$ & $\begin{array}{c}\text { Red } \\
\mathbf{( R )}\end{array}$ & $\begin{array}{c}\text { Green } \\
(\mathbf{G})\end{array}$ & $\begin{array}{c}\text { Blue } \\
(\mathbf{B})\end{array}$ & $\begin{array}{c}\text { Pixel } \\
\text { Grayscale } \\
\text { (PG) }\end{array}$ \\
\hline 0031 & 527027 & 5599257 & 400973 & 40190 \\
\hline 0032 & 321708 & 3351319 & 249449 & 31884 \\
& 1 & & 5 & \\
\hline 0033 & 402101 & 4249527 & 305169 & 31428 \\
& 3 & & 2 & \\
\hline 0034 & 552129 & 5854731 & 404934 & \\
& 6 & & 0 & 42801 \\
\hline 0035 & 470426 & 4947879 & 346486 & 36475 \\
& 6 & & 3 & \\
\hline 0036 & 513893 & 5427898 & 363477 & \\
& 3 & & 1 & 44893 \\
\hline $\begin{array}{l}\text { Rata- } \\
\text { Rata }\end{array}$ & 464547 & 4905102 & 345081 & 37945.17 \\
\hline
\end{tabular}

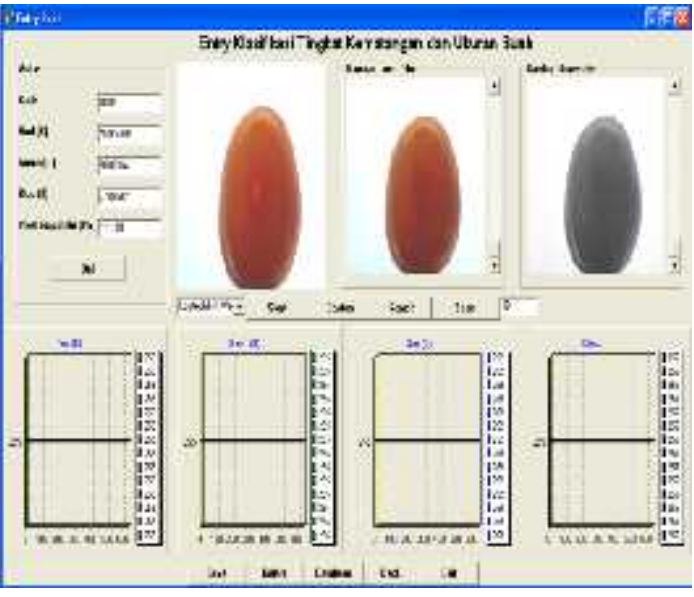

Gambar 8. Hasil dari Pengambilan Data Tomat Matang - Besar No.1 pada Tabel

\section{PEMBAHASAN}

Setelah didapatkan data sampel yang dijadikan referensi, lalu dilakukan pengujian terhadap objek buah tomat. Untuk buah tomat matang-besar dilakukan pengujian sebanyak 20 kali. Dari 20 data tersebut teridentifikasi sebanyak 9 kali.

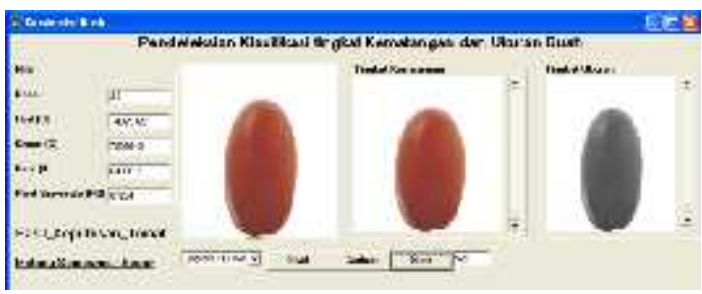

Gambar 9. Pendeteksian Tomat MatangBesar

Untuk buah tomat matang-sedang dilakukan uji identifikasi sebanyak 12 kali Dari hasil pengujian tersebut sistim mampu mendeteksi secara keseluruhan atau 12 kali terdeteksi dengan benar.

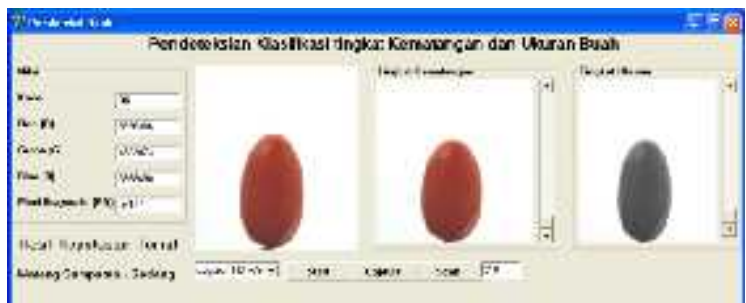


Gambar 10. Pendeteksian Tomat Matang-Sedang

Untuk buah tomat matang-kecil diambil data identifikasi sebanyak 11 kali data uji, dimana dari 11 data uji tersebut teridentifikasi sebanyak 11 kali.

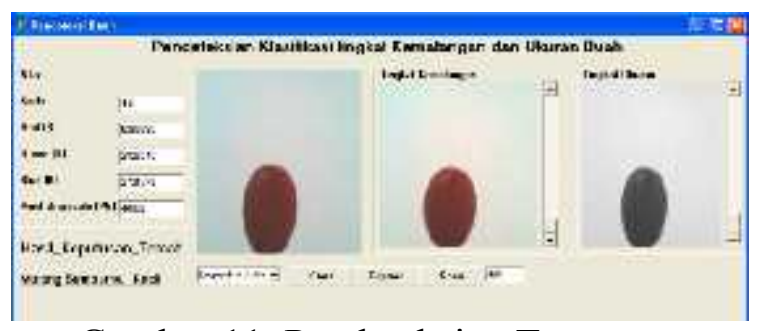

Gambar 11. Pendeteksian Tomat Matang-Kecil

Untuk buah tomat muda-besar diambil data identifikasi sebanyak 10 buah data, dari 10 data tersebut teridentifikasi sebanyak 10 data.

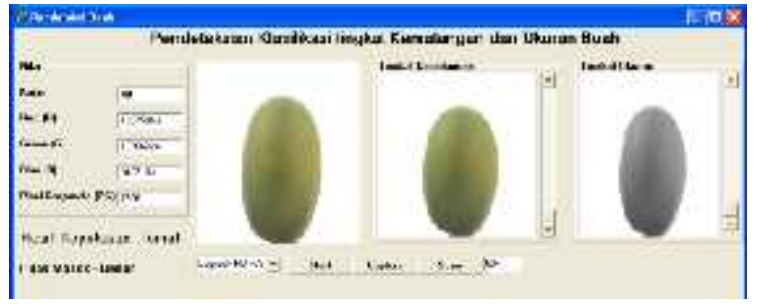

Gambar 12. Pendeteksian Tomat MudaBesar

Untuk buah tomat muda-sedang diambil data identifikasi sebanyak 12 buah data, dari 12 data tersebut teridentifikasi sebanyak 12 data.

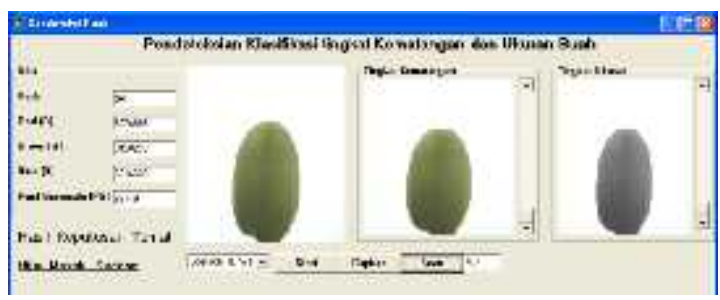

Gambar 13. Pendeteksian Tomat MudaSedang

Untuk buah tomat muda-kecil diambil data identifikasi sebanyak 12 buah data, dari 12 data tersebut teridentifikasi sebanyak 3 kali.

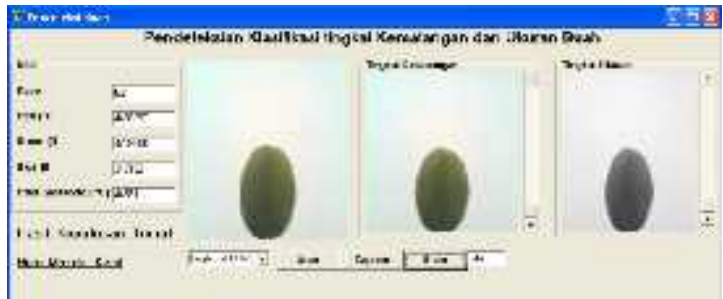

Gambar 14. Pendeteksian Tomat MudaKecil

Pada 65 kali pengujian data diatas, 56 kali pengujian yang berhasil dideteksi sedangkan 9 kali belum berhasil yaitu untuk uji tomat muda-kecil. Dari 32 kali pendeteksian tomat matang dari berbagai ukuran (besar, sedang dan kecil) berhasil mengidentifikasi $100 \%$, sedangkan untuk tomat muda, yang berhasil teridentifikasi 25 kali dari 34 pengujian yaitu $73 \%$. Persentase keberhasilan keseluruhan tomat matang dan muda adalah:

$$
\begin{aligned}
& \frac{\text { Hasil pengujian yang berhasil }}{\text { Total Pengujian }} \times 100 \% \\
& \frac{56}{65} \times 100 \%=86,15 \%
\end{aligned}
$$

Tingkat keberhasilan pengujian terhadap keseluruhan tomat adalah sebesar 86,15 $\%$. Pengujian yang dilakukan pada tomat yang tidak teridentifikasi itu adalah tomat muda (warna hijau) yang berukuran kecil, hal ini dipengaruhi oleh faktor cahaya pada sekeliling buah tomat. Secara keseluruhan cahaya sangat mempengaruhi sistem image processing ini dalam mengklasifikasi tingkat kematangan. Sedangkan untuk pengklasifikasian tomat berdasarkan ukuran berhasil teridentifikasi 100\%.

\section{KESIMPULAN}

Dari hasil pengujian yang dilakukan dan analisa tentang pendeteksian kematangan 
dan ukuran buah tomat, maka dapat ditarik kesimpulan sebagai berikut:

1. Sistem atau program sudah dapat membedakan antara tomat masak (matang) dan muda (belum matang) untuk tingkat kematangan, sedangkan untuk ukuran tomat sudah dapat dipisahkan menjadi tiga kelas, yaitu kecil, sedang dan besar.

2. Untuk pendeteksian tomat berdasarkan ukuran sudah sangat baik karena tomat yang dideteksi oleh sistem ini hampir sama dengan klasifikasi visual penglihatan manusia secara umum.

3. Pendeteksian untuk tingkat kematangan tomat dipengaruhi oleh pencahayaan saat capture, dimana persentasi keberhasilan pendeteksian tomat masak sebesar $100 \%$ sedangkan pada pendeteksian tomat belum masak sebesar $73 \%$.

\section{SARAN}

1. Untuk klasifikasi tingkat kematangan perlu diatur pencahayaan yang tepat pada saat capture objek, karena sangat mempengaruhi hasil identifikasi.

2. Tindak lanjut penelitian ini adalah dengan mengabungkan sistem ini dengan sistem selektor otomatis.

\section{DAFTAR PUSTAKA}

[1]Adhi, Tria Wijaya dan Yudi Prayudi. 2010. Implementasi Visi Komputer dan Segmentasi Citra untuk Klasifikasi Bobot Telur Ayam Ras. Jurnal seminar nasionalaplikasi teknologi informasi (SNATI), http://scribd.com, Diakses tanggal 11 April 2012
[2]Achmad, Balza. 2005. Teknik Pengolahan Citra Digital Menggunkan Delphi. Jakarta

[3]Ahmad, Usman. 2005. Pengolahan Citra Digital \& Teknik Pemrogramannya. Graha Ilmu, Yogyakarta

[4]Anonymous.Citra.Fttp://download.co $\mathrm{m} /$ segmentasi/peng\%20citra\%20dgita 1.htm, Diakses tanggal 5 April 2012

[5]Anonymous. Landasan Teori. $\mathrm{fttp}: / /$ download.com/jbptunikomppgdl-s1-2007-alanbudiha-6252-babii/pdf, Diakses tanggal 2 April 2012

[6]Anonymous. Tanpa tahun. Pengolahan. http://download.com/ Segmentasi\%20Citra\%20for\%205572 1048-PengolahanCitra.htm, Diakses tanggal 5 April 2012

[7]Anonymous. 2007. Pengolahan Citra Digital.

http://download.com/wikipediaPengolahanCitraDigital.htm, Diakses tanggal 5 April 2012

[8]Anonymous. Tanpa tahun . Segmentasi Citra Digital .http://www.scribd.com/chick ennita/d/79749059/60-SegmentasiCitra, Diakses tanggal 25 April 2012

[9]Fadlisyah. 2004. Computer Vision dan Pengolahan Citra. Andi, Yogyakarta

[10]Gonzales, wood. 1993. Citra Digital dan Implementasinya. Erlangga, Jakarta

[11]Hestiningsih, Idhawati. 2009. Pengolahan Citra. http://www.google.com/--idhawatihe-47-1-pengolah-a/pdf, Diakses tanggal 2 April 2012

[12]Herdy, Bagus Firmanto. 2011. Sukses Bertanam Tomat Secara. Angkasa, Bandung

[13]Heru, Yoyok. Perancangan Software Capture dan Segmentasi, Halaman 121-131. http://scribd.com. Diakses tanggal 26 April 2012

[14]Iswahyudi, Catur. 2010. Prototype Aplikasi Untuk Mengukur 
Kematangan Buah Apel Berdasar Kemiripan Warna. Jurnal Fakultas Teknologi Industri Institut Sains \& Teknologi AKPRIND Yogyakarta. Tidak diterbitkan

[15]Jain, Anil K. 1989. Fundamentals of Digital Image Processing. PrenticeHall International.

[16]Kusnaariyanto. 2011. Belajar Pemrograman Delphi. Modula, Bandung

[17]Pressman, Roger S. 2002. Rekayasa Perangkat Lunak Pendekatan Praktisi (Buku Satu). Andi, Yogyakarta

[18]Rangkuti, Haris dan Marimin. 2008. Analisis Citra Buah-Buahan Dengan Algoritma Fagin dan Threshold. Jurnal nasional aplikasi teknologi

(SNATI). http://scribd.com. Diakses tanggal 2 April 2012

[19]Rijal, Yusron dan Riza Dhian Ariefianto. Deteksi Wajah Berbasis Segmentasi Model Warna Menggunakan Template Matching Pada Objek Bergerak. Jurnal Seminar Nasional Aplikasi Teknologi Informasi 2008 (SNATI 2008). http://script.com. Diakses tanggal 26 Arril 2012

[20]Sutoyo. 2009. Citra Digital. Graha ilmu, Yogyakarta

[21]Munir, Rinaldi. 2004. Pengolahan Citra Digital dengan Pendekatan Algoritmatik. Informatika, Bandung

[22]Tim Bina Karya Tani. 2009. Budidaya Tanaman. Yrama Widya, Bandung

[23]Thiang, Leonardus Indrotanoto. 2008 . Otomatisasi Pemisah Buah Tomat Berdasarkan Ukuran dan Warna Menggunakan Webcam Sebagai Sensor. Jurnal seminar nasional ilmu komputer dan aplikasinya (SNIKA). http://scribd.com. Diakses tanggal 11 Juli 2012
[24]Wibisono, Setyawan. 2009. Klasifikasi Tingkat Ketuaan Cabe Merah

Besar.http://www.google.com/jurna 1/kalsifikasi-tingkat-ketuaan/pdf.

Diakses tanggal 1 April 2012


ISSN :2085-6989 